\title{
Mulching Implication on Productivity and Fruit Quality of Pomegranate Grown In A Sandy Soil
}

\author{
A.A. E-Taweel ${ }^{*}$ and A.A. Farag ${ }^{* *}$ \\ *Olive and Fruits of Semi-Arid Zone Department, Horticulture \\ Research institute and ${ }^{* *}$ Central Laboratory for Agricultural \\ Climate, Agriculture Research Centre, Cairo, Egypt.
}

\begin{abstract}
7 HIS STUDY was carried out during two successive seasons (2012 and 2013) on 4 - years old pomegranate trees, (Punica granatum L.) wonderful cv., grown on a sandy soil under drip irrigation to assess four different mulching treatments, rice straw, palm fronds, transparent polyethylene sheets and gravel on tree growth and their productivity. The design of the experiment is randomized complete block five treatments with three replicates each.

Gravel mulch gave the highest number of leaves, shoot length, number of internodes, as well as length, diameter, volume, aril weight per fruit, fruit weight and yield. Rice straw gave the highest total soluble solids, Vitamin (C), total rind and juice anthocy anin. Gravel and rice straw mulch were more effective in reducing cracked fruits and decrease sunburn disorder. Mulching treatments reduced grass growth and increased moisture and soil temperature conservation, in particular of gravel mulch which was superior in this concern. It can be recommended that gravel mulching was the most effective treatment to improve soil moisture, growth, quality and productivity of pomegranate fruits.
\end{abstract}

Keyword: Pomegranate (Wonderful cv.), Rice straw mulch, Palm fronds mulch, Transparent polyethylene mulch, Gravel mulch. Soil temperature, Soil moisture.

Pomegranate (Punica granatum L.) belongs to the family puniceae, and is a favorite table fruit of tropical and subtropical regions of the world (Abubakr et al., 2013). Also, it has been grown in the moderate climate of the Mediterranean region. This tree species is well adapted to marginal lands and arid soils (Ozguuven et al., 2009 and Sawarsan et al., 2011). It has been cultivated from ancient times for its economic, ornamental, and medicinal properties. Globally pomegranate fruits are rather eaten fresh or used as syrup. (Abubakar et al., 2013). The wonderful pomegranate cultivar is one of the most widely grown in the world (Melgaejo et al., 2012), which fits market requirements, namely: deep red color of skin and arils and large size (Frank, 2012). In recent years, the demand has increased for increasing areas of pomegranate to face the needs of both local and foreign markets (Saeed, 2004). The total cultivated area of pomegranate in Egypt reached 26351feddans, with total fruit production of 89035 metric tons (according to the latest statistics of the Ministry of Agriculture (2012). 
Pomegranate growing is still facing many problems and procedures must be developed for better crop management (Rao and Subramanyam, 2010). Hence, improve crop management through development of appropriate research is the only alternative for better crop yield and quality (Chin et al., 2001). Agricultural management practices can change the soil surface and influence the hydrothermal properties of the soil. For example, mulching can affect the temperature and moisture content of the soil (Acharya et al., 2005), and directly influence crop yield (Liu, et al., 2014). The benefits of using mulch in orchards have been reported in many parts of the world to protect plants from extreme transpiration fluctuation (Liu et al., 2014), and regulation of soil temperature (Liang et al., 2002). In addition, soil temperature is very critical for biological and chemical process that control nutrient cycling (Donk Van et al., 2004). Moreover, using mulches help in moisture conservation and reduction of evaporation (Sinkeviciene et al., 2009), reserve water at the root zone (Khalifa, 1994), increased soil organic matter (Kristina et al., 2013), and it is considered as a source of plant nutrients (Hostetler et al., 2007). The use of mulches from different sources may increase or decrease the availability of nutrient absorption of roots (Payam et al., 2013). Many kinds of mulching are used in production practices. The two major types of mulch are inorganic and organic (Liang et al., 2002 and Payam et al., 2013). Inorganic mulches include various types of gravel, stone and plastic. (Yuan et al., 2009 and Aly et al., 2010). Organic mulching uses rice straw, palm leaf, compost, and banana leaves. The present work aimed to study the effect of different mulching materials (organic and inorganic) on the growth and productivity of pomegranate trees (Wonderful cv.).

\section{Material and methods}

\section{Field Study}

This investigation was carried out during two growing seasons of 2012 and 2013 on four- years old pomegranate trees Wonderful cv., grown on sandy soil at a private orchard at Kilometer 75 from Cairo-Alexandria desert road. The trees were almost uniform in their shape and size. The treatments comprised five mulch material (rice straw (Oryza sativa, L.) at $15 \mathrm{~cm}$. thickness, Palm fronds (Phoenix dactylifera L.) was add in two layers on soil, transparent polyethylene mulch with 50 micron thick, gravel at thickness range from 1.7 to $7 \mathrm{~cm}$ and bar soil ). All treatments were applied on both sides of the tree row on February until the end of November. The distances between trees are $3 \mathrm{~m}$ in the row and $5 \mathrm{~m}$ between rows about 280 trees per feddan.

\section{Climate data.}

Air temperature and relative humidity

The daily maximum and minimum temperature and relative humidity were recorded by weather station in the Cairo-Alexandria road. The average of 15days for maximu $\mathrm{m}$ and minimum temperature and relative humidity were recorded.

Egypt. J. Hort. Vol. 42, No.1 (2015) 
Soil temperature.

Soil temperature was measured at $10 \mathrm{~cm}$ depth at $1 \mathrm{pm}$. every 15 days from March to end of September under different mulch treatments and bar soil, content.

Soil moisture

Soil moisture was measured by using soil moisture meter model (PMS-714). Measurement range: $0 \%$ to $50 \%$ moisture content of soil sample with $0.1 \%$ resolution at $10 \mathrm{~cm}$ depth at time of $1 \mathrm{pm}$. every 15 day from March to end of September under different mulch treatments and bar soil.

Soil properties

The soil physical and chemical properties data were tabulated in Tables (1 \& 2).

TABLE 1. The physical properties of the soil experiment analyzed before treatment.

\begin{tabular}{|c|c|c|c|c|c|}
\hline Depth cm & Sand \% & Clay\% & Silt \% & Texture & Sp \% \\
\hline $0-30 \mathrm{~cm}$ & 97.8 & 1.0 & 1.2 & sandy & 23 \\
\hline
\end{tabular}

TABLE 2. The chemical properties of the soil experiment analyzed before treatment.

\begin{tabular}{|c|c|c|c|c|c|c|c|c|c|c|c|}
\hline \multirow{2}{*}{$\begin{array}{c}\text { Depth } \\
\text { Cm }\end{array}$} & \multirow{2}{*}{ pH } & \multirow{2}{*}{$\begin{array}{c}\text { ECe } \\
\mathrm{dS} / \mathrm{m}\end{array}$} & \multicolumn{4}{|c|}{ Cations meq/l } & \multicolumn{4}{|c|}{ Anionsmeq/l } & \multirow{2}{*}{ SAR } \\
\hline & & & $\mathrm{Ca}^{++}$ & $\mathbf{M g}^{++}$ & $\mathrm{Na}^{+}$ & $\mathbf{K}^{+}$ & $\mathrm{Cl}^{-}$ & $\mathrm{CO}_{3}^{--}$ & $\mathrm{HCO}_{3}^{-}$ & $\mathrm{SO}_{4}{ }^{--}$ & \\
\hline $0-30$ & 8.17 & 0.65 & 3.0 & 1.2 & 2.0 & 0.3 & 2.0 & 0.0 & 2.4 & 2.1 & 1.4 \\
\hline
\end{tabular}

Growth performance

In each study season, twenty shoots of one-year sprout were tagged randomly at different sides of the trees to determine the number of leaves, shoot length and the number of internodes.

Flowering and yield

The date of flowering was estimated at the beginning of flowering, number of both male, hermaphrodite flowers were counted at the ballon stage and fruit setting percentage were recorded per tree on the twenty tagged shoots. Final fruit set were counted and yield consequently calculated as average fruit weight was multiplied by the number of the resulted fruit in both of the study seasons.

\section{Physical Characteristics of the fruit}

Three replicates of fruits, each one contain five fruits, were used to determine fruit physical characteristics by recording fruit weight, fruit volume, fruit length, fruit diameter and shape index. Selected fruits were peeled by hand in the laboratory, then, their rind was separately and weighted, thus calculating the aril (edible part) weight/fruit. 
Fruit chemical properties

Total soluble solids (T.S.S\%) was measured by a hand refractometer. Acidity of fruit juice was determined by titration with 0.1 normal sodium hydroxide with phenolphthalein as an indicator, according to A.O.A.C. (1985), then, T.S.S./acid ratio was calculated. Total sugar percentage was determined according to the method described by Dubois et al. (1956). Vitamin C content (mg.) was determined according to A.O.A.C. (1985). Total anthocyanin (mg/100 ml.) content in fruit juice and rind were measured as described by Hsia et al. (1965). Tannins content was determined in fruit juice by the method described by Winton and Winton (1945).

\section{Aril mineral composition}

A sample of 10 fruits of each treatment was randomly selected, washed and peeled by hand separately, their aril (edible part), dried at $70{ }^{\circ} \mathrm{C}$ till constant weight and grounded for the determination of the following nutrient elements:

Nitrogen: was determined by the modified Micro-Kjeldahl methods as outlined by (Pregl, 1945).

Phosphorous: was estimated by the method described by Murphy and Riley (1962).

Potassium: was determined by flame-photometer according to Chapman and Pratt (1961).

Calcium: was Spectrophoto Metrically determined using Atomic Absorption (Model, Spectronic 21 D) as described by Jackson (1973). The concentration of $\mathrm{N}, \mathrm{P}, \mathrm{K}$ and $\mathrm{Ca}$ were expressed as percent per dry weight.

\section{Economic evaluation}

Economic evaluation was calculated according to Heady and Dillon (1961)as follows:

- Total gross income $=$ total yield $(\mathrm{kg}) \times 4$ L.E.

- Gross margin= total gross income-total cost.

- Benefit/cost ratio $=$ total gross income/ total cost.

\section{Statistical analysis}

The experiment was designed in complete randomized blocks with three replicates, each replicate contains three trees. Treatment means were compared according to means in all Duncan's Multiple Range Test at 0.5 level of probability (Duncan, 1955).

\section{Results and Discussions}

\section{Air temperature and Relative humidity}

Figure 1 shows that the highest maximum temperature was, found in August (about $36^{\circ} \mathrm{C}$ ), and the lowest maximum temperature was found in March (about $21^{\circ} \mathrm{C}$ ). The minimum air temperature was higher in August (about $26^{\circ} \mathrm{C}$ ) and the lowest minimum air temperature was found in March (about $11^{\circ} \mathrm{C}$ ). Figure 2 shows maximum and minimum relative humidity during growth season. The

Egypt. J. Hort. Vol. 42, No.1 (2015) 
highest maximum relative humidity was found in June (about $84 \%$ ) and the lowest was found in April (about $16 \%$ ).

Hot and dry climate during pomegranate fruit development improves fruit quality. The pomegranate was affected if the temperature remains below $11^{\circ} \mathrm{C}$ for a longer time. Humid climate during fruit setting adversely affects fruit color development, quality and increases pest and disease attack (Hess-Pierce and Kader, 2003).

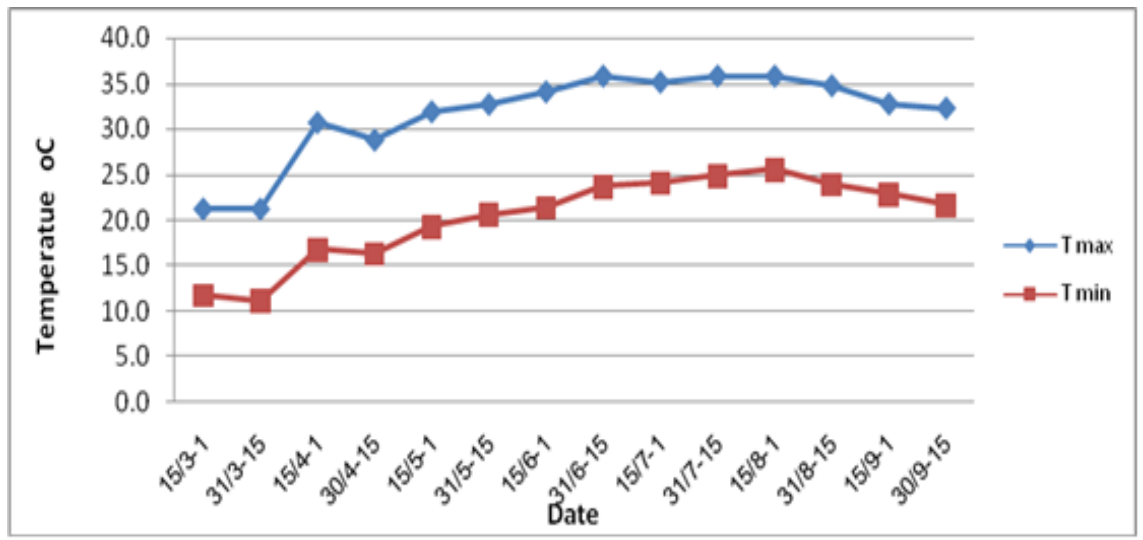

Fig. 1. Maximum and minimum air temperature in Alex. desert road area, average of two years (2012 and 2013).

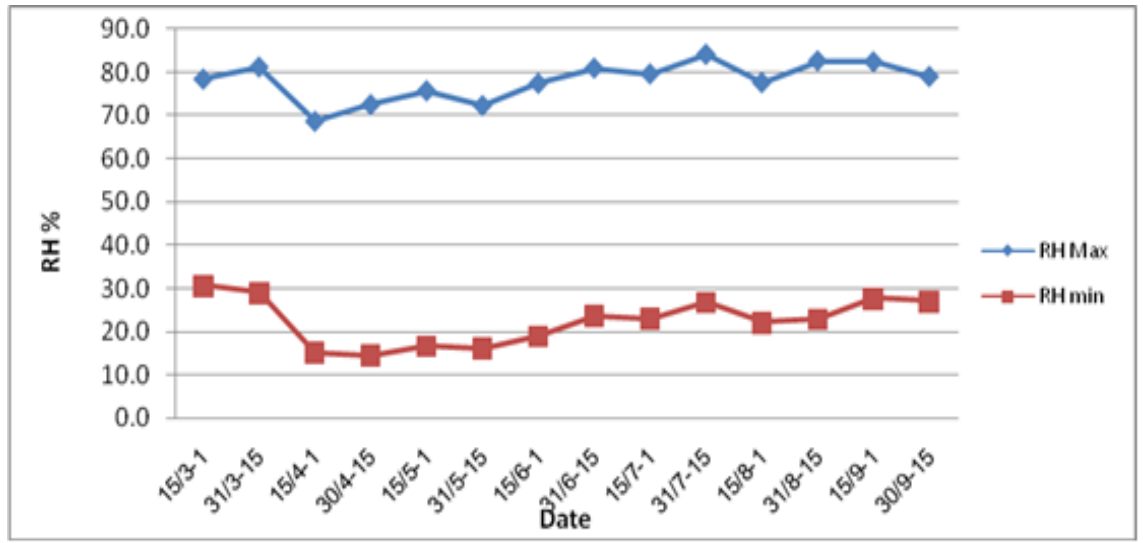

Fig. 2. Maximum and minimum Relative Humidity in Alex. desert road area, average of two years (2012 and 2013).

Soil temperature

Average soil temperature at $10 \mathrm{~cm}$ depth under different mulch marital from March to September was shown in Fig. 3. During the crop cycle, the highest soil 
temperature was found under the transparent mulch (PE) followed by gravel. At the same period, soil temperature under bare soil was lower than under the transparent plastic by $2-3^{\circ} \mathrm{C}$. The difference in soil temperature between gravel and bare soil was about $1.8-2.5^{\circ} \mathrm{C}$. The rice straw increased soil temperature than bare soil ranged from 1.2 to $2.1^{\circ} \mathrm{C}$. The nearest soil temperature to the bare soil was found in Palm fronds with difference about $0.9-1.3^{\circ} \mathrm{C}$.

Anikwe et al. (2007) observed that the unmulched plots had the lowest soil temperature (about $1-3.80^{\circ} \mathrm{C}$ lower) at different times since planting compared to plastic film mulched plots. Among different mulching techniques plastic film mulching increases soil surface temperature by influencing the heat balance and thus increased the soil temperature and it positively influenced the crop emergence (Aniekwe et al., 2004).

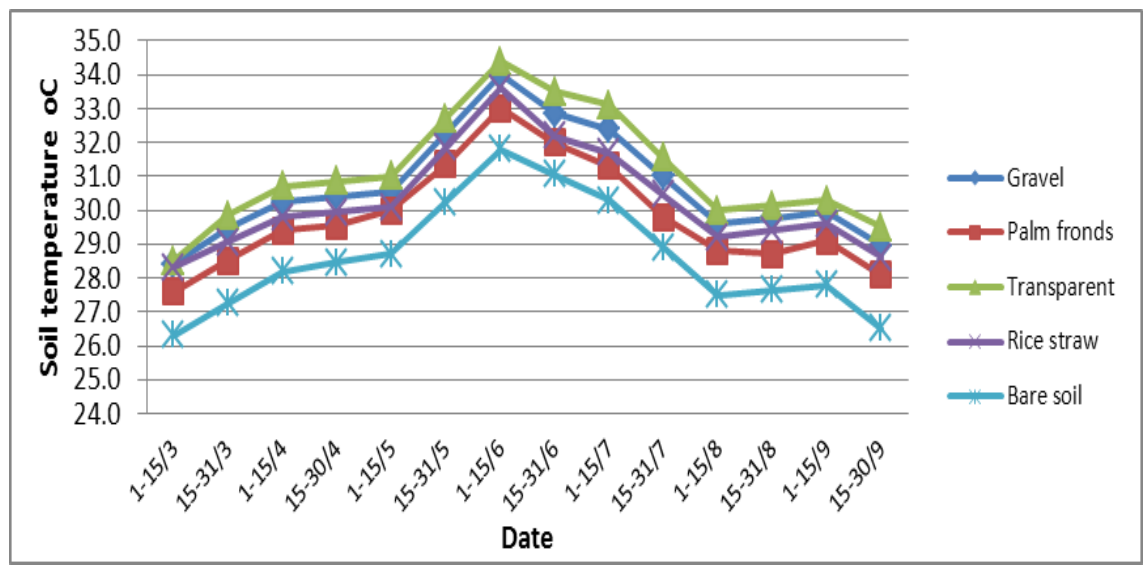

Fig. 3. Soil temperature under different mulch materials in Alex. Desert road farm, average of two years (2012 and 2013).

\section{Soil moisture}

Average soil moisture at $15 \mathrm{~cm}$ depth under different mulch marital from March to September was presented in Fig. 4. The highest soil moisture was found under gravel mulch followed by transparent mulch. The average soil moisture under bar soil was the lowest one about $15.9 \%$ while the highest average soil moisture was found under gravel about $29.2 \%$ followed by transparent mulch about $25 \%$ and $22.4 \%$ under Rice straw mulch.

The higher soil water content in the mulch treated soils was due to a combination of reduced evaporation loss and greater soil water conservation because of reduced weed growth. A common practice today in modern pomegranate orchards is to use mulches. Such mulches conserve soil moisture, reducing water consumption by $20 \%$ to $25 \%$ and significantly reduce weed population by $20 \%$ to $26 \%$ as compared to controls (Aulakh \& Sur 1999, Chan el al ., 2010 and Ravid et al., 2004).

Egypt. J. Hort. Vol. 42, No.1 (2015) 


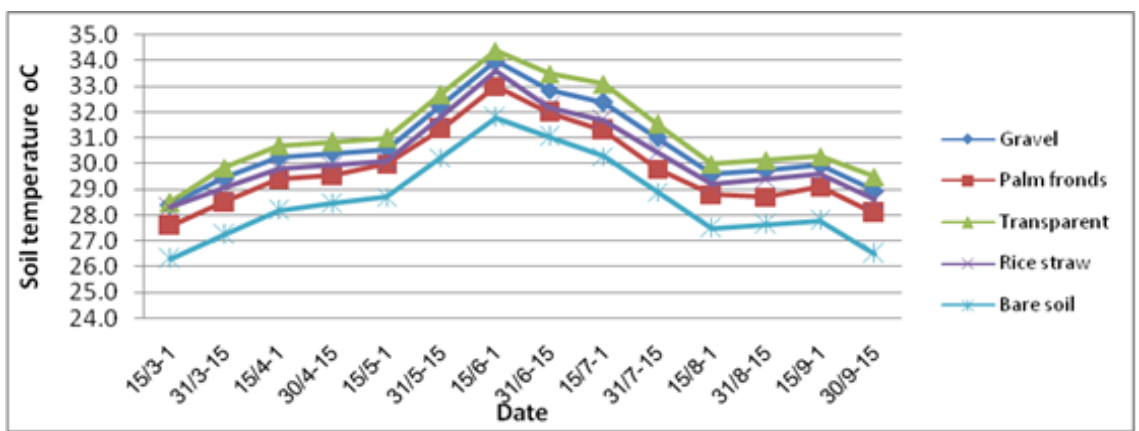

Fig. 4. Soil moisture under different mulch material in Alex. Desert road farm, average of two years (2012 and 2013).

\section{Soil properties after treatment}

Table 3 shows that soil organic matter was affected by different types of mulches. The highest soil organic matter was observed in rice straw $(2.40 \%)$ followed by palm fronds $(2.00 \%)$. Mulching can contribute to such a development by improving organic matter content in the soils and by affecting other soil characteristics (Ferrini et al., 2008). Covering the soil with different type of mulches improve environmental conditions for soil organic matter via, preventing of water and wind erosion, inhibiting drastic variation in humidity and temperature (Jodaugiene et al., 2010).

Soil available phosphorus was affected by different types of mulch. The highest soil available phosphorus was observed in rice straw $(2.75 \mathrm{~kg} / 100 \mathrm{~g})$ followed by palm fronds $(2.60 \mathrm{~kg} / 100 \mathrm{~g})$. These findings are in close conformity with tendency of a higher amount of available phosphorus in the soil in mulched plots was determined by Sinkeviciene et al., (2009).

Soil available potassium was also affected by different types of mulch. The highest soil available potassium was observed in soil covered with rice straw (45 $\mathrm{kg} / 100 \mathrm{~g}$ ) followed by palm fronds $(43 \mathrm{~kg} / 100 \mathrm{~g})$ and the lowest was observed without mulch treatment $(26 \mathrm{~kg} / 100 \mathrm{~g})$. Organic mulches probably have much more potassium in their structure and regulation of soil temperature and moisture which helped increase soil available potassium by Vijay (2014).

TABLE 3. Evaluation of main properties of soil after 2-years from treatment.

\begin{tabular}{|l|c|c|c|}
\hline \multirow{2}{*}{\multicolumn{1}{c|}{ Treatment }} & *OM & $\mathbf{P}$ & $\mathbf{K}$ \\
\cline { 2 - 4 } & $\mathbf{( \% )}$ & \multicolumn{2}{|c|}{$\mathbf{k g ~ / 1 0 0 ~ g}$} \\
\hline Control & 1.80 & 2.50 & 26 \\
\hline Rice straw & 2.40 & 2.75 & 45 \\
\hline Palm frands & 2.00 & 2.60 & 43 \\
\hline Transparent & 1.80 & 1.70 & 34 \\
\hline Gravel & 1.80 & 1.73 & 35 \\
\hline
\end{tabular}

* $\mathrm{OM}=$ organic matter. 
Effect of mulching on some vegetative growth aspects:

Number of leaves /shoot

Data presented in Table 4 shows that number of leaves/twig in gravel mulch applications were (54.10 \& 74.07) if compared with control (31.10 \& 37.83) during both seasons. Yamanaka et al. (2004) stated that the evaporation processes under gravel mulches were much more stable. Pang et al. (2012) showed that the soil moisture and microbial quantity increased when mulched by gravel and sand. Hence, this could increase nutrients uptake and translocation of nutrients. Many investigators supported these findings (Belatus, 2002). In addition to that, Moslem et al. (2012) reported that, all treatments of mulching significantly increased the number of leaves of fig trees compared with control.

\section{Shoot length and number of internodes}

The effect of mulching on shoot growth and internodes of pomegranate wonderful cultivar is presented in Table 4, it is obvious, that shoot growth parameters (length and number of internodes) significantly influenced by the treatments.

The highest shoot length was recorded with gravel mulch treatment $(32.83 \&$ $37.62 \mathrm{~cm}$ ) during the two seasons. As for internodes, gravel also was the superior in both seasons $(14.67 \& 18.23 \mathrm{~cm})$ if compared with the control. The obtained data show that gravel acts an activation which increased shoot length and number of internodes. Zhang et al. (2010), reported that soil moisture content in apple trees zone was the highest with gravel mulch treatment. This could be possible due to increase intensive metabolic processes (Lei et al., 2012).

The above mentioned are in harmony with those of Verma et al. (2005), who reported that mulching improved vegetative growth of apple trees and distribution of roots and their absorption of nutrients.

TABLE 4. Effect of mulching on some morphological properties of wonderful cv. pomegranate trees /branch /meter during 2012 and 2013 seasons.

\begin{tabular}{|l|c|c|c|c|c|c|}
\hline \multirow{2}{*}{ Treat } & \multicolumn{2}{|c|}{ No. of leaves/shoot } & \multicolumn{2}{c|}{ Shoot length (cm) } & \multicolumn{2}{c|}{ No. of internodes } \\
\cline { 2 - 7 } & $\mathbf{2 0 1 2}$ & $\mathbf{2 0 1 3}$ & $\mathbf{2 0 1 2}$ & $\mathbf{2 0 1 3}$ & $\mathbf{2 0 1 2}$ & $\mathbf{2 0 1 3}$ \\
\hline Control & $31.10 \mathrm{CD}$ & $37.83 \mathrm{C}$ & $21.63 \mathrm{BC}$ & $22.47 \mathrm{D}$ & $10.77 \mathrm{C}$ & $11.73 \mathrm{D}$ \\
\hline Rice straw & $33.67 \mathrm{BC}$ & $46.23 \mathrm{~B}$ & $23.07 \mathrm{~B}$ & $26.83 \mathrm{~B}$ & $12.67 \mathrm{~B}$ & $14.67 \mathrm{~B}$ \\
\hline Palm frands & $28.67 \mathrm{D}$ & $34.33 \mathrm{C}$ & $20.73 \mathrm{C}$ & $22.60 \mathrm{D}$ & $11.00 \mathrm{C}$ & $13.13 \mathrm{C}$ \\
\hline Transparent & $36.80 \mathrm{~B}$ & $48.43 \mathrm{~B}$ & $21.60 \mathrm{BC}$ & $25.07 \mathrm{C}$ & $11.33 \mathrm{C}$ & $13.67 \mathrm{BC}$ \\
\hline Gravel & $54.10 \mathrm{~A}$ & $74.07 \mathrm{~A}$ & $32.83 \mathrm{~A}$ & $37.62 \mathrm{~A}$ & $14.67 \mathrm{~A}$ & $18.23 \mathrm{~A}$ \\
\hline
\end{tabular}

Effect of mulching on flowering characteristics and fruit set percentage

Data presented in Table 5 illustrate the effect of tested treatments on flowering characteristics as, total male flowers, total hermaphrodite, number of total flowers/twig and sex ratio of wonderful $\mathrm{cv}$. pomegranate trees. The

Egypt. J. Hort. Vol. 42, No.1 (2015) 
obtained show that the control treatment had the highest male flowers $(45.33 \&$ 48.67) meanwhile the lowest values of total male flowers /twig were recorded for rice straw mulch application (32.76 \& 35.07) in the first and second seasons, respectively. Regarding the highest number of hermaphrodite flowers/twig were observed with transparent polyethylene mulch treatment (48.0) in the first season and gravel (48.33) in the second season, respectively. Concerning the number of total flowers/twig, control treatments recorded the maximum number of total flowers/twig (86.33) in the first season and transparent (86.13) in the second season, respectively. The highest sex ratios were recorded with transparent polyethylene mulch treatments in the first season seasons (57.24) and for gravel mulch (56.08) in the second season compared to the control in both season, respectively. As regarding the effect of used mulching treatments on fruit set percentage, data showed the highest values (64.33\%) for the application transparent polyethylene mulch in the first season and for rice straw mulch $(65.50 \%)$ in the second one. the least values $(46.20 \& 48.40 \%)$ are resulted from the control treatment in both seasons, respectively. These results in general are in agreement with those of (Liu et al., 2014) on citrus. Improving soil characteristics using mulching increased water uptake by regulating the stoma and preventing excessive water loss through transpiration. In addition, soil mulching with plastic film results in reducing water loss and regulating soil temperature, which has been widely used in agriculture (Zhang et al., 2010). However, other reported that soil temperature has a dominant influence on plant growth (Willis and Power, 1975). They all suggested that, higher moisture and temperature and better nutrient availability, through the reduction of leaching offered by mulching, may be the reason for the increase in fruit physical properties (Aly et al., 2010) on Anna apple trees.

TABLE 5. Effect of mulching on flowering characteristics and fruit set percentage of Wonderful cv. Pomegranate trees during 2012 and 2013 seasons.

\begin{tabular}{|c|c|c|c|c|c|c|c|c|c|c|}
\hline \multirow{2}{*}{ Treat } & \multicolumn{2}{|c|}{$\begin{array}{c}\text { Total male } \\
\text { flowers/twig. }\end{array}$} & \multicolumn{2}{|c|}{\begin{tabular}{|c} 
Total \\
hermaphrodite \\
/ twig
\end{tabular}} & \multicolumn{2}{|c|}{$\begin{array}{l}\text { T. flowers } \\
\text { / twig }\end{array}$} & \multicolumn{2}{|c|}{ Sex ratio } & \multicolumn{2}{|c|}{$\begin{array}{c}\text { Fruit set } \\
(\%)\end{array}$} \\
\hline & 2012 & 2013 & 2012 & 2013 & 2012 & 2013 & 2012 & 2013 & 2012 & 2013 \\
\hline Control & 45.33 & 48.67 & $44.00 \mathrm{~A}$ & 36.93 & 86.33 & 85.60 & 50.99 & 43.16 & 46.20 & 48.40 \\
\hline $\begin{array}{l}\text { Rice } \\
\text { straw }\end{array}$ & $\begin{array}{c}32.67 \\
\mathrm{C}\end{array}$ & $\begin{array}{c}35.07 \\
\mathrm{~B}\end{array}$ & $\begin{array}{c}38.10 \\
\mathrm{C}\end{array}$ & $\begin{array}{c}34.50 \\
\mathrm{C}\end{array}$ & $\begin{array}{c}67.57 \\
\mathrm{C}\end{array}$ & $\begin{array}{c}69.60 \\
\text { B }\end{array}$ & $\begin{array}{c}56.68 \\
A\end{array}$ & $\begin{array}{c}49.49 \\
\text { B }\end{array}$ & $\begin{array}{c}63.63 \\
\mathrm{~A}\end{array}$ & $\begin{array}{c}65.50 \\
\mathrm{~A}\end{array}$ \\
\hline $\begin{array}{l}\text { Palm } \\
\text { frands }\end{array}$ & $\begin{array}{c}34.33 \\
\mathrm{C}\end{array}$ & $\begin{array}{c}38.33 \\
\mathrm{~B}\end{array}$ & $\begin{array}{c}43.00 \\
\text { B }\end{array}$ & $\begin{array}{c}44.87 \\
\text { A }\end{array}$ & $\begin{array}{c}77.33 \\
\text { B }\end{array}$ & $\begin{array}{c}83.20 \\
\mathrm{~A}\end{array}$ & $\begin{array}{c}55.62 \\
A\end{array}$ & $\begin{array}{c}53.92 \\
\mathrm{~A}\end{array}$ & $\begin{array}{l}8.83 \\
\mathrm{C}\end{array}$ & $\begin{array}{c}50.20 \\
\mathrm{C}\end{array}$ \\
\hline $\begin{array}{l}\text { Transpar } \\
\text { ent }\end{array}$ & $\begin{array}{c}37.00 \\
\text { BC }\end{array}$ & $\begin{array}{c}38.33 \\
\mathrm{~B}\end{array}$ & $\begin{array}{c}48.00 \\
\mathrm{~A}\end{array}$ & $\begin{array}{c}47.80 \\
\mathrm{~A}\end{array}$ & $\begin{array}{c}74.00 \\
\text { BC }\end{array}$ & $\begin{array}{c}86.13 \\
\mathrm{~A}\end{array}$ & $\begin{array}{c}57.24 \\
\mathrm{~A}\end{array}$ & $\begin{array}{c}55.44 \\
\mathrm{~A}\end{array}$ & $\begin{array}{c}64.33 \\
\mathrm{~A}\end{array}$ & $\begin{array}{c}65.13 \\
\mathrm{~A}\end{array}$ \\
\hline Gravel & $\begin{array}{c}40.33 \\
\mathrm{~B}\end{array}$ & $\begin{array}{c}37.33 \\
\mathrm{~B}\end{array}$ & $\begin{array}{c}40.33 \\
\mathrm{BC}\end{array}$ & $\begin{array}{c}48.33 \\
\mathrm{~A}\end{array}$ & $\begin{array}{c}80.67 \\
\mathrm{AB}\end{array}$ & $\begin{array}{c}85.67 \\
\text { A }\end{array}$ & $\begin{array}{c}49.84 \\
\text { B }\end{array}$ & $\begin{array}{c}56.08 \\
\mathrm{~A}\end{array}$ & $\begin{array}{c}52.67 \\
\text { B }\end{array}$ & $\begin{array}{c}56.73 \\
\text { B }\end{array}$ \\
\hline
\end{tabular}

Values within column having different letters showed statistically significant differences $(p<0.05)$. 


\section{Effect of mulching on fruit physical properties \\ Fruit length, diameter, shape index}

The effect of tested treatments on fruit length, diameter and shape index of wonderful $\mathrm{cv}$. pomegranate trees presented in Table 6 . The obtained indicated that all mulching used treatments significantly increased the values of fruit length and diameter in both seasons. In this respect, gravel mulch treatment gave higher values of fruit length $(9.20 \& 10 \mathrm{~cm})$ and fruit diameter $(10.00 \& 11 \mathrm{~cm})$ in the first and second seasons, respectively. The least values of fruit length $(8.20$ and $8.33 \mathrm{~cm})$ and fruit diameter $(8.33$ and 8.93$)$ were obtained for untreated tree in the both seasons, respectively. As regarding fruit shape index, the control treatment had the highest values meanwhile the least values recorded for other mulching treatments and the differences between them were not significant in both seasons. Hence, this indicates that gravel mulch may play an important role in promoting and enhancing physiological processes, uptake and root activation due to the mechanism of evaporation restriction. Gravel mulches may be breaking the continuity of capillary force preventing the movement of liquid water in the macro pores among gravel. Due to this, soil water vaporizes at the soil surface and diffuses through the macro pores amongst the gravels into the atmosphere in the form of vapor (Yuan et al., 2009). The obtained results are in accordance with those reported by (Liang, 2002), (Payam, et al., 2013) and recently by (Vijay, 2014).

Fruit volume, juice volume and rind thickness

Data presented in Table 6 revealed that the values of fruit volume, juice volume and rind thickness were significantly increased with application of used mulching treatments. As fruit volume, gravel mulch is much better whereas that treatment had the highest values of these characters $\left(627.3 \& 679.0 \mathrm{~cm}^{3}\right)$ for fruit volume, $\left(161.7\right.$ and $\left.146.7 \mathrm{~cm}^{3}\right)$ for juice volume and $(0.78$ and $0.73 \mathrm{~cm})$ for rind thickness during both seasons, respectively. Control treatment gave the last values in this respect. These results emphasize that gravel mulch treatment has a pertinent role on fruit quality. With respect to the effect of rice straw on rind thickness, this kind of mulch material can be explained by release nutrients and provide other special effects (Liang, et al., 2002), reported that organic mulch material can be decomposed to release nutrient and provided other special effect. Khorsandi (2011) reported that gravel mulch increases infiltration of water and soil moisture storage. This could be possible due to increase the nutrients uptake. Moreover, mulching plays an important role in the development of potassiumdeficiency (Aly et al., 2010).

\section{Aril fruit weight, 100 aril weight, and aril weight ratio}

Data presented in Table 6 revealed that a significant response of the tested mulches treatments on aril weight fruit, 100 aril weight and aril weight ratio of wonderful pomegranate trees. Gravel mulch treatment gave the highest values of aril fruits weight $(255.0 \& 270.0 \mathrm{~g})$ and highest values of 100 -aril weight $(40.33$ and $43.26 \mathrm{~g}$ ) in the first and second season, respectively. Control treatment gave the lowest values in this respect. Concerning aril fruit weight ratio, results cleared that the application of rice straw was the superior treatment $(0.56 \& 0.54)$ during the two studied seasons, respectively.

Egypt. J. Hort. Vol. 42, No.1 (2015) 
TABLE 6. Effect of mulches on fruit physical properties of Wonderful cv. pomegranate trees during 2012 and 2013 seasons.

\begin{tabular}{|c|c|c|c|c|c|c|}
\hline \multirow{2}{*}{ Treat } & \multicolumn{2}{|c|}{ Fruit length (cm) } & \multicolumn{2}{|c|}{ Fruit diameter (cm) } & \multicolumn{2}{|c|}{ F. shape index } \\
\hline & 2012 & 2013 & 2012 & 2013 & 2012 & 2013 \\
\hline Control & $8.20 \mathrm{C}$ & $8.33 \mathrm{D}$ & $8.33 \mathrm{D}$ & $8.93 \mathrm{D}$ & $1.05 \mathrm{~A}$ & $1.03 \mathrm{~A}$ \\
\hline Rice straw & $8.23 \mathrm{C}$ & $9.50 \mathrm{~B}$ & $9.50 \mathrm{~B}$ & $10.0 \mathrm{C}$ & $0.87 \mathrm{~B}$ & $0.88 \mathrm{~B}$ \\
\hline Palm frands & $8.30 \mathrm{C}$ & $9.33 \mathrm{BC}$ & $9.33 \mathrm{BC}$ & 10.40B & $0.88 \mathrm{~B}$ & $0.88 \mathrm{~B}$ \\
\hline Transparent & $8.57 \mathrm{~B}$ & $9.23 \mathrm{C}$ & $9.23 \mathrm{C}$ & $10.27 \mathrm{BC}$ & $0.89 \mathrm{~B}$ & $0.88 \mathrm{~B}$ \\
\hline Gravel & $9.20 \mathrm{~A}$ & $10.00 \mathrm{~A}$ & $10.00 \mathrm{~A}$ & $11.00 \mathrm{~A}$ & $0.92 \mathrm{~B}$ & $0.86 \mathrm{~B}$ \\
\hline \multirow{2}{*}{ Treat } & \multicolumn{2}{|c|}{ Fruit volume $\left(\mathrm{cm}^{3}\right)$} & \multicolumn{2}{|c|}{ Juice volume $\left(\mathrm{cm}^{5}\right)$} & \multicolumn{2}{|c|}{ Rind thickness (cm) } \\
\hline & 2012 & 2013 & 2012 & 2013 & 2012 & 2013 \\
\hline Control & $388.2 \mathrm{D}$ & 400.9D & $110.0 \mathrm{D}$ & $73.33 \mathrm{E}$ & $0.70 \mathrm{AB}$ & $0.67 \mathrm{~B}$ \\
\hline Rice straw & $457.3 \mathrm{C}$ & $513.3 \mathrm{C}$ & $155.3 \mathrm{~B}$ & $99.33 \mathrm{D}$ & $0.74 \mathrm{AB}$ & $0.73 \mathrm{~A}$ \\
\hline Palm frands & $516.7 \mathrm{~B}$ & $566.7 \mathrm{~B}$ & $159.7 \mathrm{~A}$ & $134.3 \mathrm{C}$ & $0.67 \mathrm{~B}$ & $0.70 \mathrm{AB}$ \\
\hline Transparent & $520.7 \mathrm{~B}$ & 549.3B & $149.7 \mathrm{C}$ & 141.7B & $0.67 \mathrm{~B}$ & $0.67 \mathrm{~B}$ \\
\hline Gravel & $627.3 \mathrm{~A}$ & $679.0 \mathrm{~A}$ & $161.7 \mathrm{~A}$ & $146.7 \mathrm{~A}$ & $0.78 \mathrm{~A}$ & $0.73 \mathrm{~A}$ \\
\hline \multirow[t]{2}{*}{ Treat } & \multicolumn{2}{|c|}{$\begin{array}{l}\text { Aril fruit weight } \\
\text { (gm) }\end{array}$} & \multicolumn{2}{|c|}{$\begin{array}{c}100 \text { aril weight } \\
(\mathrm{gm})\end{array}$} & \multicolumn{2}{|c|}{$\begin{array}{l}\text { Aril/fruit weight } \\
\text { ratio }\end{array}$} \\
\hline & 2012 & 2013 & 2012 & 2013 & 2012 & 2013 \\
\hline Control & $184.4 \mathrm{C}$ & $192.0 \mathrm{C}$ & $35.19 \mathrm{~B}$ & $39.80 \mathrm{~B}$ & $0.53 \mathrm{AB}$ & $0.51 \mathrm{AB}$ \\
\hline Rice straw & $236.8 \mathrm{AB}$ & $252.7 \mathrm{AB}$ & $40.15 \mathrm{~A}$ & $41.52 \mathrm{AB}$ & $0.56 \mathrm{~A}$ & $0.54 \mathrm{~A}$ \\
\hline Palm frands & $225.3 \mathrm{~B}$ & $246.6 \mathrm{~B}$ & $38.78 \mathrm{~A}$ & $40.52 \mathrm{~B}$ & $0.47 \mathrm{C}$ & $0.45 \mathrm{BC}$ \\
\hline Transparent & $238.0 \mathrm{AB}$ & $244.5 \mathrm{~B}$ & $35.27 \mathrm{~B}$ & $40.04 \mathrm{~B}$ & $0.49 \mathrm{BC}$ & $0.45 \mathrm{BC}$ \\
\hline Gravel & $255.0 \mathrm{~A}$ & $270.8 \mathrm{~A}$ & $40.33 \mathrm{~A}$ & $43.26 \mathrm{~A}$ & $0.44 \mathrm{C}$ & $0.41 \mathrm{C}$ \\
\hline
\end{tabular}

Values within column having different letters showed statistically significant differences $(\mathrm{p}<0.05)$.

\section{Effect of mulching on fruit chemical properties}

Total soluble solids, acidity, T.S.S / acid ratio and vitamin C.

Data presented in Table 7 showed a significant effect of used different mulches on total soluble solids, total acidity, T.S.S/acid and Vitamin C. For T.S.S., it is obvious that rice straw mulch was the superior in the first and second seasons $(15.67 \& 16.43 \%)$ followed by palm fronds mulch in the first season $(15.63 \%)$ and gravel mulch in the second season $(15.88 \%)$. These results coincided with Vijar (2014). Moreover, Green and Rakow (1995) who reported that organic mulches probably have much more potassium in their structure and with the regulation of soil temperature and moisture they helped to increasing soil available potassium. Also, Rakow (1989) confirmed that the use of mulches with different sources may increase or decrease the ability of root nutrients to absorb. This emphasized that potassium has an important role in promoting and enhancing the physiological processes (Al-Taweel, 2001). Also, De et al. (2005) mentioned that, Banana leaves increased soil moisture contents at varying degrees.

Regarding total acidity, the highest percentage of acidity is recorded with untreated control $(1.98$ and $1.80 \%)$ in the first and second seasons, respectively. 
Meanwhile the lowest values (1.79 and 1.69\%) were obtained from rice straw mulch treatment in the first and second seasons, respectively. Concerning the T.S.S./acid ratio, the results revealed that rice straw mulch treatment had higher values (8.75 and 9.72), on the other hand the lowest values recorded for control treatment (7.54 and 8.34) in the first and second seasons, respectively. As for vitamin $C$, the more effective treatment was the rice straw mulch (14.55 and 13.82) while untreated trees gave the lowest values (12.57 and 12.45) in the first and second seasons, respectively. The ripe fruit which had a low acid content, titratable acidity reduction can be used as a standard criterion to detect maturation (Mehdi et al., 2011). The maturity index (T.S.S./acid ratio) also appeared to be a good indicator of fruit maturity. The effects of mulching tend to slightly reduce total acidity and therefore the ratio of T.S.S./acid increased in the fruit juice of the treated trees than the control. These findings were agreed with reported by (Meiyan et al., 2009 and Zarei et al., 2011). In addition, this emphasize that $\mathrm{K}$. output of rice straw treatment has a pertinent role on fruit quality of Kadota fig Cultivar (Adel and Ahmed, 2011).

Total sugars, tannins, total rind and juice anthocyanin

The effect of mulch treatments on total sugars $(\mathrm{mg} / 100 \mathrm{ml})$, tannins $(\mathrm{mg} / 100 \mathrm{ml})$, total juice $(\mathrm{mg} / 100 \mathrm{ml})$ and total rind anthocyanin $(\mathrm{mg} / 100 \mathrm{ml})$ of Wonderful cv. pomegranate trees are shown in Table 7 . The results revealed that, the highest values of total sugars was obtained from transparent mulch (13.40) followed by palm fronds (13.35), rice straw (13.07) and gravel mulch (13.03) in the first season. While gravel mulch, gave the highest (13.88) in the second season followed by transparent (13.03). These results may be due to mulching plays an important role in the development of potassium-deficiency (Aly et al., 2010). Concerning, tannins (mg/100m), From the data presented in Table (7), it is clear that tannins recorded the highest values with the control treatment $(2.68 \&$ 2.64), while transparent mulch recorded the lowest values $(2.40 \& 2.20)$ in the first and second seasons, respectively.

As for total rind and juice anthocyanin $(\mathrm{mg} / 100 \mathrm{~g})$ rice straw mulch treatment gave significantly the highest values $(0.71 \& 0.84 \mathrm{mg} / 100 \mathrm{~g})$ and $(1.42 \& 1.52$ $\mathrm{mg} / 100 \mathrm{~g}$ ) during both seasons, respectively. The lowest values resulted from the control treatment. This is probably due to the fact that Tannins are metabolites, which defend plants from herbivores by protein precipitation (Zarei et al., 2011). On other hand, rice straw mulch found to positively impact citrus fruit yield in extreme weather conditions (Liu et al., 2014). This may be due to the improvement of soil characteristics and nutrient status and its important role in translocation compounds which increase fruit quality(Ramalan and Nwokeocha, 2000).

Egypt. J. Hort. Vol. 42, No.1 (2015) 
TABLE 7. Effect of mulching on fruit chemical properties of Wonderful cv. Pomegranate trees during 2012 and 2013 seasons.

\begin{tabular}{|c|c|c|c|c|c|c|c|c|}
\hline \multirow[t]{2}{*}{ Treat } & \multicolumn{2}{|c|}{ TSS (\%) } & \multicolumn{2}{|c|}{ Acidity (\%) } & \multicolumn{2}{|c|}{ TSS/acid } & \multicolumn{2}{|c|}{\begin{tabular}{|c|} 
Vitamin $(\mathrm{C}) \mathrm{mg}$ \\
ascorbic acid $/ 100 \mathrm{ml}$ \\
juice \\
\end{tabular}} \\
\hline & 2012 & 2013 & 2012 & 2013 & 2012 & 2013 & 2012 & 2013 \\
\hline Control & $14.93 \mathrm{~B}$ & $15.12 \mathrm{C}$ & $1.98 \mathrm{~A}$ & $1.80 \mathrm{~A}$ & $7.54 \mathrm{C}$ & $8.34 \mathrm{C}$ & $12.57 \mathrm{D}$ & $12.45 \mathrm{E}$ \\
\hline Rice straw & $15.67 \mathrm{~A}$ & $16.43 \mathrm{~A}$ & $1.79 \mathrm{C}$ & $1.69 \mathrm{~B}$ & $8.75 \mathrm{~A}$ & $9.72 \mathrm{~A}$ & $14.55 \mathrm{~A}$ & $13.82 \mathrm{~A}$ \\
\hline Palm frands & $15.63 \mathrm{~A}$ & 15.70B & $1.87 \mathrm{~B}$ & $1.78 \mathrm{~A}$ & $8.36 \mathrm{~A}$ & $8.82 \mathrm{~B}$ & $13.55 \mathrm{~B}$ & $13.10 \mathrm{C}$ \\
\hline Transparent & $15.10 \mathrm{~B}$ & $15.80 \mathrm{~B}$ & $1.90 \mathrm{C}$ & $1.75 \mathrm{AB}$ & $7.95 \mathrm{~B}$ & $9.03 \mathrm{~B}$ & $13.90 \mathrm{~B}$ & $13.47 \mathrm{~B}$ \\
\hline Gravel & $15.20 \mathrm{~B}$ & $15.88 \mathrm{~B}$ & $1.93 \mathrm{AB}$ & $1.70 \mathrm{~B}$ & $7.94 \mathrm{~B}$ & $9.34 \mathrm{~A}$ & $13.0 \mathrm{C}$ & $12.79 \mathrm{D}$ \\
\hline \multirow[t]{2}{*}{ Treat } & \multicolumn{2}{|c|}{ T. sugars $(\%)$} & \multicolumn{2}{|c|}{ Tannins (\%) } & \multicolumn{2}{|c|}{$\begin{array}{c}\text { Total rind } \\
\text { anthocyanin } \\
(\mathrm{mg} / \mathbf{1 0 0 g})\end{array}$} & \multicolumn{2}{|c|}{$\begin{array}{c}\text { Total juice } \\
\text { anthocyanin } \\
(\mathrm{mg} / \mathbf{1 0 0 g})\end{array}$} \\
\hline & 2012 & 2013 & 2012 & 2013 & 2012 & 2013 & 2012 & 2013 \\
\hline Control & $11.95 \mathrm{~B}$ & $12.13 \mathrm{C}$ & $2.68 \mathrm{~A}$ & $2.64 \mathrm{~A}$ & $0.31 \mathrm{~B}$ & $0.43 \mathrm{C}$ & $0.84 \mathrm{D}$ & $0.90 \mathrm{D}$ \\
\hline Rice straw & $13.07 \mathrm{~A}$ & $12.97 \mathrm{~B}$ & $2.43 \mathrm{~B}$ & $2.21 \mathrm{C}$ & $0.71 \mathrm{~A}$ & $0.84 \mathrm{~A}$ & $1.42 \mathrm{~A}$ & $1.52 \mathrm{~A}$ \\
\hline Palm frands & $13.35 \mathrm{~A}$ & $12.90 \mathrm{~B}$ & $2.45 \mathrm{~B}$ & $2.23 \mathrm{C}$ & $0.65 \mathrm{~A}$ & $0.65 \mathrm{~B}$ & $1.12 \mathrm{C}$ & $1.25 \mathrm{C}$ \\
\hline Transparent & $13.4 \mathrm{~A}$ & $13.03 \mathrm{~B}$ & $2.40 \mathrm{~B}$ & $2.20 \mathrm{C}$ & $0.66 \mathrm{~A}$ & $0.71 \mathrm{~B}$ & $1.10 \mathrm{C}$ & $1.33 \mathrm{~B}$ \\
\hline Gravel & $13.03 \mathrm{~A}$ & $13.88 \mathrm{~A}$ & $2.50 \mathrm{~B}$ & $2.32 \mathrm{~B}$ & $0.67 \mathrm{~A}$ & $0.67 \mathrm{~B}$ & $1.29 \mathrm{~B}$ & $1.39 \mathrm{~B}$ \\
\hline
\end{tabular}

Values within column having different letters showed statistically significant differences $(\mathrm{p}<0.05)$.

\section{Effect of mulching on fruiting and yield}

Data presented in Table 8 revealed that the tested treatments significantly increased average fruit weight, total number of fruits/tree and yield $(\mathrm{Kg} / \mathrm{tree})$ of Wonderful cv. pomegranate trees as compared with control during both seasons. In this concern, application of gravel mulch treatment presented heaviest fruit weight $(575.2 \& 609.8 \mathrm{~g})$ followed by rice straw mulch $(557.1 \& 556.8 \mathrm{~g})$ while control treatment had the lowest weight (375.8 and $381.9 \mathrm{~g}$ ) in the first and second seasons, respectively. The other treatment were in between. As for total number of fruits/tree, gravel mulch was the highest values $(57.33 \& 64.33)$ on the other hand, the least values resulted from control treatment (44.0 \& 42.67) in both seasons, respectively. Concerning yield $(\mathrm{Kg} / \mathrm{tree})$ the results in Table (8) revealed that all mulching materials applied had a pronounced increase of yield. The effect was higher with application of gravel mulch (32.98 \& 39.23) followed by rice straw mulch $(30.27 \& 34.15 \mathrm{Kg})$ while the least values are resulted from control $(16.54 \& 16.30 \mathrm{Kg})$ during both seasons, respectively. The present data are in accordance with many previous works like (Adel and Ahmed 2001), (Aly et al., 2010), and (Liu et al., 2014). 
TABLE 8. Effect of mulching on fruiting and yield of wonderful cv. pomegranate trees during 2012 and 2013 seasons.

\begin{tabular}{|l|c|c|c|c|c|c|}
\hline \multirow{2}{*}{ Treat } & \multicolumn{2}{|c|}{$\begin{array}{c}\text { Av. Fruit weight } \\
\text { (g.) }\end{array}$} & \multicolumn{2}{c|}{ Total No. of fruits/tree } & \multicolumn{2}{c|}{ Yield/tree (Kg.) } \\
\cline { 2 - 8 } & $\mathbf{2 0 1 2}$ & $\mathbf{2 0 1 3}$ & $\mathbf{2 0 1 2}$ & $\mathbf{2 0 1 3}$ & $\mathbf{2 0 1 2}$ & $\mathbf{2 0 1 3}$ \\
\hline Control & $375.8 \mathrm{D}$ & $381.9 \mathrm{D}$ & $44.00 \mathrm{~B}$ & $42.67 \mathrm{C}$ & $16.54 \mathrm{D}$ & $16.30 \mathrm{E}$ \\
\hline Rice straw & $557.1 \mathrm{~A}$ & $556.8 \mathrm{~B}$ & $54.33 \mathrm{~A}$ & $61.33 \mathrm{~A}$ & $30.27 \mathrm{~A}$ & $34.15 \mathrm{~B}$ \\
\hline Palm frands & $481.8 \mathrm{~B}$ & $539.2 \mathrm{~B}$ & $54.67 \mathrm{~A}$ & $53.33 \mathrm{~B}$ & $26.34 \mathrm{~B}$ & $28.76 \mathrm{C}$ \\
\hline Transparent & $431.6 \mathrm{C}$ & $476.0 \mathrm{C}$ & $54.33 \mathrm{~A}$ & $49.33 \mathrm{~B}$ & $23.45 \mathrm{C}$ & $23.48 \mathrm{D}$ \\
\hline Gravel & $575.2 \mathrm{~A}$ & $609.8 \mathrm{~A}$ & $57.33 \mathrm{~A}$ & $64.33 \mathrm{~A}$ & $32.98 \mathrm{~A}$ & $39.23 \mathrm{~A}$ \\
\hline
\end{tabular}

Values within column having different letters showed st atistically significant differences $(\mathrm{p}<0.05)$.

Effect of mulching on sunburn and crack ed fruits percentage

Data presented in Table 9 shows that transparent mulch application, had an obvious increase in sunburn $(6.67 \% \& 9.67 \%)$ followed by control treatment $(5.33 \% \& 4.67 \%)$ during both seasons, respectively. The least values are recorded with the application of rice straw (3.33 and 2.67\%) in the first and second seasons respectively. Concerning cracked fruits, Table (9) showed that the application of gravel and rice straw treatments gave the least values compared to other treatments. This may be due to the role of rice straw and gravel mulch applications in promoting and enhancing the metabolic process and regulate water balance (Yajun et al., 2011 and Liu et al., 2014) who confirmed that the effect of straw mulching on Citrus fruit yield could be positive in extreme weather condition. Gravel mulch also prevents soil surface from being directly exposed to solar radiation, which prevents the reduction of surface soil water vaporization and in heat energy absorption (Yuan et al., 2009).

TABLE 9. Effect of mulching treatments on fruit sunburn and cracks during 2012 and 2013 seasons.

\begin{tabular}{|l|c|c|c|c|}
\hline \multirow{2}{*}{ Treat } & \multicolumn{2}{|c|}{ Sun burnt fruits (\%) } & \multicolumn{2}{c|}{ Cracked fruits (\%) } \\
\cline { 2 - 5 } & $\mathbf{2 0 1 2}$ & $\mathbf{2 0 1 3}$ & $\mathbf{2 0 1 2}$ & $\mathbf{2 0 1 3}$ \\
\hline Control & $5.33 \mathrm{~A}$ & $4.67 \mathrm{~B}$ & $1.67 \mathrm{~A}$ & $1.00 \mathrm{~A}$ \\
\hline Rice straw & $3.33 \mathrm{~B}$ & $2.67 \mathrm{D}$ & $0.00 \mathrm{C}$ & $0.00 \mathrm{C}$ \\
\hline Palm frands & $3.33 \mathrm{~B}$ & $4.33 \mathrm{BC}$ & $1.00 \mathrm{~B}$ & $0.67 \mathrm{~B}$ \\
\hline Transparent & $6.67 \mathrm{~A}$ & $9.67 \mathrm{~A}$ & $1.33 \mathrm{AB}$ & $1.00 \mathrm{~A}$ \\
\hline Gravel & $3.33 \mathrm{~B}$ & $3.00 \mathrm{CD}$ & $0.00 \mathrm{C}$ & $0.00 \mathrm{C}$ \\
\hline
\end{tabular}

Values within column having different letters showed st atistically significant differences $(p<0.05)$.

10. Effect of mulching on aril content of nitrogen, phosphorus, potassium and calcium (\%)

The obtained results presented in Table (10) revealed that transparent polyethylene treatment resulted in a high Nitrogen values $(1.84,1.93 \%)$ followed by palm fronds $(1.81,1.89 \%)$, with control treatment as the least $(1.21,1.22 \%)$

Egypt. J. Hort. Vol. 42, No.1 (2015) 
during the two seasons, respectively. Antonious et al. (1996) reported that transparent polyethylene mulch reflected the largest amount of blue light. In addition, Decoteau et al. (1988) believed that shorter and more auxiliary growth could result from blue light reflected by transparent polyethylene mulch. Liang et al. (2002) reported that palm fronds mulch can be decomposed to release nutrients and provide other special effects.

Phosphorus content during the two seasons was affected by gravel mulch treatment as significant increase in phosphorus contents $(0.61,0.64)$ was observed during the two seasons of the study, respectively. Thus could be due to the increase of soil moisture and the soil microbial quantity when mulched by gravel and sand (Lei et al., 2012). Microorganisms in the soil play a vital role in nutrients cycling and mediate various processes through interactions with plants and other soil organis ms (Zarb et al., 1999).

Regarding the effect of mulch material on aril potassium content, data presented in Table (10) indicated that Palm fronds mulch application gave the highest values of potas sium content $(1.27 \%)$ in the first season, whereas rice straw gave the highest $(1.31 \%)$ in the second season. As for the control treatment, it gave the lowest values of $\mathrm{k}$ content $(1.07,1.01 \%)$ at the both season, respectively.

Vijay (2014) found that organic mulches probably have much more potassium in their structure and with the regulation of soil temperature and moisture they helped in increasing soil available potassium. Finally, using of different mulches lead to the increase in N. P. K., and, Ca contents in the aril mineral composition (Aly et al., 2010).

Calcium content in the aril mineral composition has been affected by the us ed mulching application. (Table 10) a significant increase in calcium content with application of rice straw mulch $(1.19 \%)$ in the first season and with palm fronds in the second one $(1.25 \%)$. It could be concluded from the obtained results that organic mulches eventually breaks down and becomes a part of the soil and a source of plant nutrients (Sharma et al., 1998).

TABLE 10. Aril mineral composition of the studied Wonderful cv. pomegranate during 2012 and 2013 seasons.

\begin{tabular}{|l|c|c|c|c|c|c|c|c|}
\hline \multirow{2}{*}{ Treat } & \multicolumn{2}{|c|}{$\mathbf{N}(\boldsymbol{\%})$} & \multicolumn{2}{c|}{ P (\%) } & \multicolumn{2}{c|}{ K (\%) } & \multicolumn{2}{c|}{ Ca (\%) } \\
\cline { 2 - 9 } & $\mathbf{2 0 1 2}$ & $\mathbf{2 0 1 3}$ & $\mathbf{2 0 1 2}$ & $\mathbf{2 0 1 3}$ & $\mathbf{2 0 1 2}$ & $\mathbf{2 0 1 3}$ & $\mathbf{2 0 1 2}$ & $\mathbf{2 0 1 3}$ \\
\hline Control & $1.21 \mathrm{D}$ & $1.22 \mathrm{E}$ & $0.33 \mathrm{E}$ & $0.36 \mathrm{E}$ & $1.07 \mathrm{D}$ & $1.01 \mathrm{E}$ & $1.05 \mathrm{D}$ & $1.10 \mathrm{E}$ \\
\hline Rice straw & $1.46 \mathrm{C}$ & $1.55 \mathrm{D}$ & $0.55 \mathrm{~B}$ & $0.59 \mathrm{~B}$ & $1.22 \mathrm{~B}$ & $1.31 \mathrm{~A}$ & $1.19 \mathrm{~A}$ & $1.22 \mathrm{~B}$ \\
\hline Palm fronds & $1.81 \mathrm{~A}$ & $1.89 \mathrm{~B}$ & $0.49 \mathrm{C}$ & $0.51 \mathrm{C}$ & $1.27 \mathrm{~A}$ & $1.25 \mathrm{~B}$ & $1.16 \mathrm{~B}$ & $1.25 \mathrm{~A}$ \\
\hline Transparent & $1.84 \mathrm{~A}$ & $1.93 \mathrm{~A}$ & $0.40 \mathrm{D}$ & $0.42 \mathrm{D}$ & $1.01 \mathrm{E}$ & $1.11 \mathrm{D}$ & $1.17 \mathrm{~B}$ & $1.20 \mathrm{C}$ \\
\hline Gravel & $1.65 \mathrm{~B}$ & $1.69 \mathrm{C}$ & $0.61 \mathrm{~A}$ & $0.64 \mathrm{~A}$ & $1.16 \mathrm{C}$ & $1.23 \mathrm{C}$ & $1.11 \mathrm{C}$ & $1.18 \mathrm{D}$ \\
\hline
\end{tabular}

Values within column having different letters showed st atistically significant differences $(\mathrm{p}<0.05)$. 
Effect of mulches on dry cut grass weight

Results presented in Table 11 shows that application of mulching should be recommended for the control of weeds. Existing weeds are Ipomoea L., characterized as naturalized in sandy places (Tackholm, 1974). All mulching treatments showed a clear effect on weeds in pomegranate orchards. Bare soil gave the highest values of cut grass weight $(74.89 \& 80.75 \mathrm{gm})$ respectively in both seasons. Mulching with rice straw, palm fronds residues, transparent polyethylene and gravel found to be a good practice for controlling weeds in pomegranate orchards could be used effectively for controlling weeds in pomegranate orchards. The efficiency of mulching in controlling weeds also has benefits on soil environment. (Handa, 1991). These results are in line with those obtained by Abo El-Wafa et al. (2012), Adel \& Ahmed (2011) and Amini \& Morteza (2013). In addition, Paolo et al. (2011) reported that several studies had shown that full season competition due to unmanaged weeds could cause reduction in yield of up to $37 \%$.

TABLE 11. Effect of some mulching materials on cut grass weight (g) during 2012 and 2013 seasons.

\begin{tabular}{|l|c|c|}
\hline \multirow{2}{*}{ Treat } & \multicolumn{2}{|c|}{ Dry cut grass weight(g) } \\
\cline { 2 - 3 } & $\mathbf{2 0 1 2}$ & $\mathbf{2 0 1 3}$ \\
\hline Control & $74.89 \mathrm{~A}$ & $80.75 \mathrm{~A}$ \\
\hline Rice straw & $0.00 \mathrm{~B}$ & $0.00 \mathrm{~B}$ \\
\hline Palm fronds & $0.00 \mathrm{~B}$ & $0.00 \mathrm{~B}$ \\
\hline Transparent & $0.00 \mathrm{~B}$ & $0.00 \mathrm{~B}$ \\
\hline Gravel & $0.00 \mathrm{~B}$ & $0.00 \mathrm{~B}$ \\
\hline
\end{tabular}

Values within column having different letters showed statistically significant differences $(p<0.05)$.

\section{Economic evaluation}

Data presented in Table 12 shows the net benefit of the effect of different mulching treatments on pomegranate trees during 2012 and 2013 seasons. Mulching with gravel gave the highest benefit cost ratio (10.0 \&12.8) during both seasons, respectively. It means that everyone Egyptian pound spent on gravel treatment result in gross income of (10.0 \&12.8) in years 2012 and 2013, respectively. In addition, gravel treatment gave the highest gross margin (16566 \& 21786 L.E.) during both seasons. 
TABLE 12. Economic evaluation of the effect of some mulching material treatments on Winderful cv. pomegranate trees during 2012 and 2013.

\begin{tabular}{|c|c|c|c|c|c|c|c|c|c|c|c|c|}
\hline \multirow[t]{2}{*}{ Treatments } & \multicolumn{2}{|c|}{$\begin{array}{c}\text { Mean yield } \\
\mathrm{kg} / \mathrm{fed}\end{array}$} & \multicolumn{2}{|c|}{$\begin{array}{c}\text { Increase } \\
\text { of yield } \\
\text { kg/fed }\end{array}$} & \multicolumn{2}{|c|}{$\begin{array}{c}\text { Gross income } \\
\text { per treatment } \\
\text { L.E/fed. }\end{array}$} & \multicolumn{2}{|c|}{$\begin{array}{l}\text { Total costs } \\
\text { per } \\
\text { treatment } \\
\text { L.E/fed. }\end{array}$} & \multicolumn{2}{|c|}{$\begin{array}{c}\text { Gross } \\
\text { margin } \\
\text { L.E./fed. }\end{array}$} & \multicolumn{2}{|c|}{$\begin{array}{c}\text { Benefit } \\
\text { cost } \\
\text { ratio }\end{array}$} \\
\hline & 2012 & 2013 & 2012 & 2013 & 2012 & 2013 & 2012 & 2013 & 2012 & 2013 & 2012 & 2013 \\
\hline & 4631 & 4564 & 0 & 0 & 0 & 0 & 0 & 0 & 0 & 0 & 0 & 0 \\
\hline Ric & 6566 & 7109 & 1935 & 2545 & 7739.2 & 1.8 & 815 & 842 & 924.2 & 9338.8 & 9.5 & 12. \\
\hline $\mathrm{Pa}$ & 7330 & 7692 & 2699 & 3128 & 6.8 & 4 & 2552 & 2894 & .8 & 9616.4 & 4.2 & 4.3 \\
\hline & 8529 & 9713 & 3898 & 5149 & O. & 6.8 & 3236 & 3578 & 12354.4 & 7018. & 4.8 & 5.0 \\
\hline Gravel & 9234 & 10472 & 4603 & 5908 & 18412.8 & 23632 & 1846 & 1846 & 16566.8 & 21786 & 10.0 & 12. \\
\hline
\end{tabular}

\section{Conclusion}

According to the obtained results and discussions above, we can conclude the following:

- Soil temperature and soil moisture were greater than bare soil in case of using mulch.

- The fruit yield increased under mulch compared with bare soil.

- The application of mulch was effective in weed management in the farm.

- The Gravel mulch is recommended to obtain high production and best quality of pomegranate.

- Economically, gravel gave the highest benefit cost ratio.

- The mulch technique is considered effective method for climate change adaptation.

\section{Reference}

Abo El-Wafa, M.A., Gourgeos, K.G. and Mofeed, A.S. (2012) Effect of different irrigation levels and mulches on growth and productivity of Picual olive trees. Egypt. J. Hort., 39 (2), 89-103.

Abubakr, A.R., Ashraf, N. and Ashraf, M. (2013) Influence of plant Biostimulants on physio-chemical characteristics of pomegranate cv. Kandhari Kabuli. Journal of cell and tissue research. 13 (3): 3944-3952.

Acharya, C.l., Hati, K.M. and Bandyopadhyay, K.K. (2005) Mulches, in: Hillel D, Rosenzweig C, Pawlson DS, Sorger MI, Sparks DL, Hatfield J Editors, Encyclopedia of Soils, Elsevier puplication, pp. 521-532.

Adel, A.G. and Ahmed. M.A.H. (2011) Effect of Mulching and Glyphosate Herbicide on Growth and Fruiting of Kadota fig Cultivar (Ficus Carica L.) and Growth of Associated Weeds. Assiut J. Agric. Sci., 42 (5), 97-124.

Al-Taweel, A.A. (2001) Studies on use of potassium for quality improvement of Guava fruits. M.Sc. Thesis, Faculty of Agric. El. Mansoura Unvi., Egy pt. 
Aly, M.A., Nagwa A. Abd El-Megeed and Afaf M.A. Yousif (2010) Organic fertilization, cover crops and plastic mulching effects on soil temperature and moisture, vegetative growth, yield and fruit quality of Anna" Apple trees. Alexandria Science Exchange J., 31 (4), 394-403.

Amini, Rouhollah, and Morteza, Alami-Milani (2013) Effect of mulching on soil canopy and leaf temperature of Lentil ( Lens culenaris Medick) International Journal of Farming and Applied Sciences. 2(20), 797-802.

Aniekwe, N.L., Okereke, O.U. and Anikwe, M.A.N. (2004) Modulating effect of black plastic mulch on the environment, growth and yield of cassava in a derived savannah belt of Nigeria. Tropicultura, 22, 185-190.

Anikwe, M.A.N., Mbah, C.N., Ezeaku, P.I., Onyia, V.N. (2007) Tillage and plastic mulch effects on soil properties and growth and yield of cocoy am (Colocasia esculenta) on an ultisol in southeastern Nigeria. Soil and Tillage Research. 93, 264-272.

Antonious, G.F., Kasperbauer, M.J. and Byers, M.E. (1996) Light reflected from colored mulches to growing turnip leaves affects glucosinolate and sugar contents of edible roots. Phytochem. Photobiol., 64 (3), 605-610.

Association of Official Agricultyre Chemists (1975) "Official Methods of Analysis" A.O.A.C. $12^{\text {th }}$ ed. Published by A.O.A.C. Washington D.C. USA, 1975.

Aulakh, P.S. and Sur, H.S. (1999) Effect of mulching on soil temperature, soil moisture, weed population, growth and yield of pomegranate. Progr. Hort., 31, 131133.

Belatus, E.L. (2002) Em Technology. Regional Workshop on usage of EM Technology and agriculture waste Recyling. 26-28. March. Ministry of Agriculture . Affairs. Cairo, Egypt.

Chan, K.Y., Fahey, D.J., Newell, M. and Barchia, I. (2010) Using composted mulch in Viney ards-effects on Grape yield and quality. International J. Fruit Science, 10, 441-453.

Chapman, H.D. and Pratt, P.F. (1961) "Methods of Analysis for Soils, Plants and Waters". Div. Agric. Sci. Unvi. California, Berkely, 309p.

De, P., Chakravarti, A.K., Chakraborty, P.K. and Chakraborty, A. (2005) Study on the efficacy of some bio resources as mulch for soil moisture conservation and yield of rain fed ground nut (Archis Hypogaea). Archives of Agronomy and Soil Science. 51 (3), 247-252.

Decoteau, D. R., Kasperbauer., M.J., Daniels, D.D. and Hunt, P.G. (1988) Plastic mulch color effects on reflected light and tomato plant growth. Sci. Hort., 34,169-175.

Donk van, S.J., Tollner, E.W., S teiner, J.L. and Evett, S.R. (2004) Soil temperature under a dormant Bermuda a grass Mulch: Simulation and measurement. American Society of Agricultural Engineers, 47(1), 91-98.

Dubois, D., Gilles, K., Hamilton, J.K., Rebers, P.A. and Smith, F. (1956) A calorimetric method for the determination of sugars and related substances. Anal. Chem. $28: 350$.

Egypt. J. Hort. Vol. 42, No.1 (2015) 
Duncan, D.B. (1955) Multiple range and multiple F. Tests Biometrics, 11, 1-24.

Khorsandi, Fahad (2011) Soil water conservation by course textured volcanic rock mulch. Asian J. Exp. Biol. Sci., 2(4), 762-765.

Franck, N. (2012) The cultivation of pomegranate cv, Wonderful in Chile. Option Mediterraneenes, A, No. 103, International symposium on the pomegranate. 97-99.

Ferrini, F., Fiji, A., Pellegrino, S , Agelli, A., Platinetti, M., Frangi, P. and Amoroso, G. (2008) Effects of two organic mulches on chemical physical and biological properties. Proceedings of the $3^{\text {rd }}$ symposium, Morton Arboretum, Lisle,USA.es, 7, 485-491.

Jodaugiene, D., Pupaliene, R., Sinkeviciene, A., Marcikeiciene, A., Zebrauskayte, K., Baltaduonyie M. and Cepuliene R. (2010) The influence of organic mulches on soil biological properties . Zemdirbyste-Agrc., 97 (2), 33-40.

Green, Lee, K.M. and Rakow, D.A. (1995) The effect of wood mulch type and depth on weed and tree growth and certain soil parameters. J. Arboricult., 21(5), 225-232.

Hanada, T.I. (1991) The effect of mulching and row covers on vegetable production, Extension Bulletin. ASPAC, 332, 1- 22.

Hasia, C.L., Luh, B.S. and Chickester, C.O. (1965) Anthocy anin in Freestone Peaches. J. Food Sci., 30, 5-12.

Heady, E.O. and Dillon, J.L. (1961) Agricultural Production Functions. Iowa State University press. Iowa State University press, Iowa, U.S.A.

Hess-Pierce, B.M. and Kader, K.K. (2003) Response of 'Wonderful' pomegranates to controlled atmosphere. Acta Hort., 600-751.

Hostetler, G., Merwin, I.A., Brown, M.G. and Padilla-Zakour, O. (2007) Influence of under vine floor management on weed competition, vine nutrition and yields of Pinot noir. Amer. J. Enol. Viticult., 58, 421-430.

Jackson, M.I. (1973) Soil Chemical Analysis, Prentice Private Limited. New Delhi. Inc., India.

Khalifa, M.R. (1994) Effect of different types of mulching on water consumptive use of Valencia orange trees. J. Agric. Res. Tanta Univ., 20 (3), 591-602.

Kiristina, Batoriene, Darita, Todaugine, Rita, Pupaliene and Ausra, Sinkeviciene (2013) Effect of organic mulches on the content of organic carbon in the soil. Estonian J. Ecology, 62 (2), 100-106.

Lei, Pang, Xiao, Hong-lang, Xie, Zhong, Kui, Chai, Shou-Xi, Lu Jian- Long, Zhou, Mao-Xian, Change, Lei, Wang, Ya-Jun (2012) Effect of gravel-sand Microbial Composition. J. Desert Res., 32 (2), 351-358.

Liang, Y.I., Zhang, C.E. and Guo, D.W. (2002) Mulch types and their benefit in cropland ecosystems on the loess plateau in China. J. of Plant Nutrition, 25 (5), 945-955. 
Liu,Yi, Wang, Jing, Liu, Dongbi, Li, Zhiquo, Zhang, Guoshi, Zhang, Tao, Yong, Xie, Juan, Pan, Junfeng and Chen, Fang (2014) Straw mulching reduces the harmful effects of extreme hydrological and temperature conditions in Citrus Orchards. Plos one. 9 (1), e87094:1-9.

Mehdi, Zarei, Majid, Azizi, and Zeinolabedin, Bashir-Sadr (2011) Evaluation of physicochemical chatacteristics of pomegranate (Punica granatum L.) fruit during ripening . Fruits J. Org., 66 , 121-129.

Meiyan, Wu, Lianghuan, Wu, Limei, Zhao and Meimei, Chen (2009) Effects of continuous plastic film mulching on paddy soil bacterial. Acta Agriculturae Scandinavica Section B- Soil and Plant Science, 59, 286-294.

Melgarejo, P., Martinez, J.T., Hernandez, F., Legua., P., Melgarejo-S anchez, P. and Martinez, R. (2012) The pomegranate tree in the world : Its problems and uses. International symposium on pomegranate Bottom of from option Mediterranean, A, No 108.

Ministry of Agric, A.R.E. (2012) Agriculture Economic Bulletins. Ministry of Agric. Egypt, 2012.

Moslem, J., Haghighi, J.A.P. and Hamid, Z. (2012) Mulching impact on plant growthand production of raifed fig orchards under drought conditiond. J. Food Agri. Environment, 10 (1), 428-433.

Murphy, J. and Riley, J.P. (1962) A modified single solution method for the determination of phosphorus in natural water. Anal. Chem. Acta, 27, 31-36.

Ozguven, A.I., Yilmaz, M., Yilmaz, C. and Rehber, Y. (2009) The adaption of different pomegranate cultivars to the ecological conditions of Northern Cyprus. Acta horticulture 818, March 2009: International Sympoium on pomegranate and Minor Mediterranean fruits.

Pang, Lei, Xiao, Hong-Lang Xie, Zhong- Kui, Chai, Shou-xi., Lu, Jian-Long, Zhou, Mao- Xian, Chang, Lei and Wang, ya-Jun (2012) Effect of gravel-sand mulching on soil microbial composition. Journal of Desert Res., 32 (2), 351-358.

Paolo, P. Sanguankeo, Ramon, G. Leon and Julian, Malone (2009) Impact of weed Management Practices on Grapevine growth and Yield Components, Weed Science, 57: 103-107.

Payam, Pakdel, Ali, Tehranifar, Hossein, Nemati, Amir, Lakzian and Mahdiyeh, Kharrazi (2013) Effect of different mulching materials on soil properties under semiarid conditions in Northeastern Iran. Wudpecker J. of Agric. Res., 2 (3), 80-85.

Pregl, F. (1945) "Quantative Organic Micro-Analysis" $4^{\text {th }}$ ed., J. A. Churchill L.T.D. London, pp. 126-129.

Rakow, D.A. (1989) Types and use of mulch in the Landscape, Cornell cooperative extension fact sheet. Pages 700. 10. app.

Egypt. J. Hort. Vol. 42, No.1 (2015) 
Ramalan, A.A. and NwoKeo, C.U. (2000) Effects of furrow irrigation methods mulching and soil water suction on the growth, yield and soil water us efficiency of tomato in the Nigerian Savanna. Agric. Water Manage., 45, 317- 330.

Rao, K.D. and Subramanyam, K. (2010) Growth and yield performance of pomegranate varieties under scarce rainfall zone. Agric. l Science Digest, 30 (1), 71-72.

Saeed, W.T. (2004) Pomegranate cultivars as affected by paclobutrazol, salt stress and change in finger prints, Bull. Fac. Agric., Cairo Univ., 581-616.

Sawarsan, M.R., El-bolok, K.T. and Safia A. Abou-Taleb (2011) A comparative study on some pomegranate cultivars under the ecological conditions of Souhag Governorate, Agriculture Research J. Suez Canal University, 11 (12), 101-106.

Sharma, S., Rangger, A., Von Lutzow, M. and Insam, H. (1998) Functional of soil bacterial communities increases after maize litter amendment. European Journal of Soil Biology, 34, 53-60.

Sinkeviciene, A., Jodaugiene, D., Pupaliene, R. and Urboniene, M. (2009) The influence of organic mulches on soil properties and crop yield. Agron. Res., 7 (1), 485-491.

Tackholm, Vivi (1974) Student Flora of Egypt (second edition). Published by Cairo University. Printed by cooperative printing company, Beirut, 432.

Verma, M.L., Bhardwaj, S.P., Thakur, B.C. and Bhandria, A.R. (2005) Nutritional and mulching studies in apple. Indian. J. Hort., 62 (4), 721-730.

Vijay Kumar (2014) Effect of different organic mulching materials on soil properties of $\mathrm{Na} \mathrm{"7"} \mathrm{anola} \mathrm{(emblica} \mathrm{officinalls} \mathrm{gaerth)} \mathrm{under} \mathrm{rained} \mathrm{condition} \mathrm{of} \mathrm{shiwalik} \mathrm{foot} \mathrm{hills}$ of Himalay as India. An international quarterly Journal of life science. 9 (1), 561-564.

Willis, W.O. and Power, J.F. (1975) Soil temperature and plant growth in the Northern great plains. Wali, Mohan K., Editor, Prairie: a multiple view (proceeding of the North American Prairie conference, No. 4) University of North Dakota press, pp. 209-220.

Winton, A. H. and Winton, K. B. (1945) "Analysis of Food ", Wiley, New York, 572 p.

Yamanaka, T., Inoune, M. and Kaihotsu, I., (2004) Effects of gravel mulch on water vapor transfer above and below the soil surface. Agric. Water Manag., 67,145-155.

Yuan, Cuipin, Tingwu, Lei, Lili, Mao, Han, Liu and Yang, Wu (2009) Soil surface evaporation processes under mulches of different sized gravel. Catena J., 78, 117-121.

Zarb, J., Leifert, C. and Litterick, A. (1999) Opportunities and challenges for the use of Microbial Inoculants in agriculture practice, Proceedings of the Sixth International Conference on Kyusei Nature Farming. 28-31, October. Pretoria, South, Africa.

Zarei, M., Majid, A. and Zeinoblabedin, B.S. (2011) Evaluation of physicochemical characteristics of pomegranate (Punica granatum L.) fruit during ripening. Fruits- $J$. Org., 66 (2), 121-129. 
Zhang, Y., Xie, Y.S., Hao, M.D. and She, X.Y. (2010) Effects of different patterns surface mulching on soil properties and fruit trees growth and yield in an apple orchard. J. Applied ecology. 21 (2), 279 -286.

\section{التغطية الآثار على الإتتاجية وجودة ثمار الرمان المنزرعة فى التربة الرملية

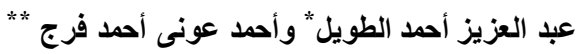

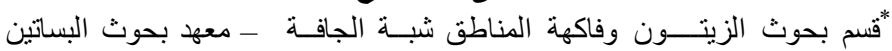

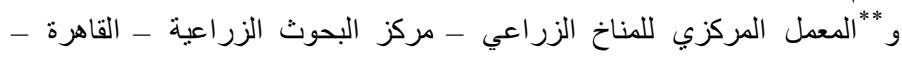

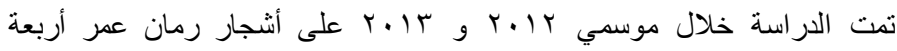

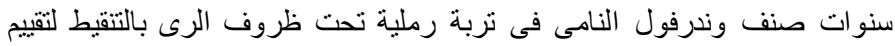

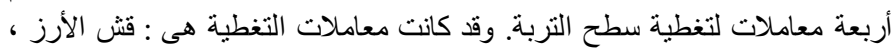

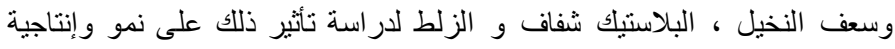

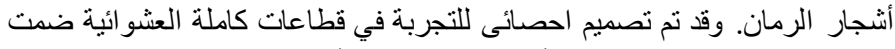

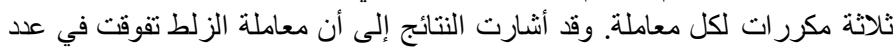

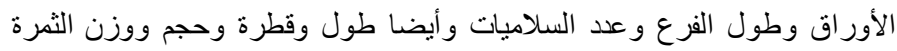

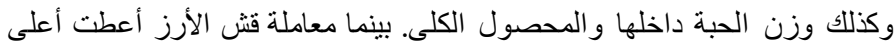

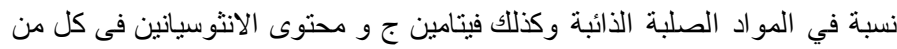

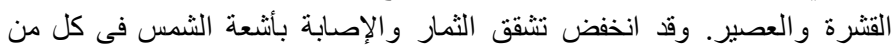

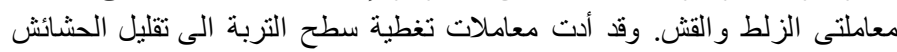

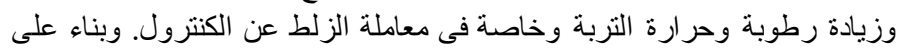

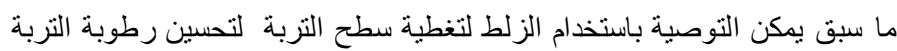
ونمو وجودة و إنتاجية أثنجار الرمان.

الكلمات الدالة : الرمان صنف وندرفول ـ ملش قش الأرز ـ ملش سعف النخيل ـ ملش البلاستيك الثفاف ـ ملش الزلط ـ ـ رطوبة التربة ـ ـ حر ارة التربة. 